\title{
Keeping the Doors Open: Commercial District Management Organizations
}

\author{
Gary Sands ${ }^{1}$, Laura A. Reese ${ }^{2} \&$ Pierre Filion $^{3}$ \\ ${ }^{1}$ Urban Planning Program, Wayne State University, Detroit, Michigan \\ ${ }^{2}$ Global Urban Studies, Michigan State University, East Lansing, Michigan \\ ${ }^{3}$ School of Planning, University of Waterloo, Waterloo, Ontario \\ Correspondence: Gary Sands, Urban Planning Program, Wayne State University. Detroit, Michigan, 48202, \\ United States. Tel: 1-734-255-5997. E-mail: gary.sands@wayne.edu
}

Received: March 17, 2014

doi: 10.5539/ibr.v7n6p18

\author{
Accepted: March 26, 2014 \\ Online Publication: May 27, 2014 \\ URL:http://dx.doi.org/10.5539/ibr.v7n6p18
}

\begin{abstract}
Commercial district organizations have been established to enhance public services, area appearance, security and economic viability. The research reported here examines two common models of commercial business district organizations, Downtown Development Authorities (DDAs) in Michigan and Business Improvement Areas (BIAs) in Canada. DDAs and BIAs typically have similar operational profiles, including marketing campaigns, events to bring customers to the area, beautification projects and member services. There are important differences, however. Business development activities are a higher priority among BIAs while capital improvements are the highest priority for DDAs. A mature DDA may face the "problem" of determining how the available funds should be spent; BIAs must find funds for the projects that they wish to undertake.
\end{abstract}

Keywords: business improvement areas, downtown development authorities, economic development Michigan, economic development Ontario

\section{Introduction}

Across North America, cities large and small face financial problems that range from serious to crisis, from short term to chronic. Revenues from traditional local sources, as well as from intergovernmental transfers, are declining while the costs of essential public services continue to rise. Local rate payers are increasingly reluctant to approve new or higher taxes; in many instances, communities are limited in their ability to generate additional revenue. The result is some combination of diminished services and deferred maintenance. Inevitably there is a decline in the quality of public services and, ultimately, in the overall quality of life in these communities.

In some instances, private interests have undertaken the provision of what have traditionally been public services. Single family residential neighborhoods, particularly new and higher income areas, may assess themselves to provide private security to complement municipal services or to support private recreational programs that are available only to resident members (Blakely \& Snyder, 1997). Residential cooperatives and condominium associations typically provide their residents with some traditionally "public" services.

Business districts have also created mechanisms to enhance public service levels related to area appearance, security and economic viability. The research reported here examines two common models of commercial business district organizations, Downtown Development Authorities (DDAs) and Business Improvement Areas (BIAs). Recent research on commercial districts has focused on three major themes: theoretical works discussing the implications and nature of the district organization as a public-private partnership; enumeration of the activities and services of business district associations; and, assessments of their efficiency and effectiveness (Stokes, 2007).

Overall, research on commercial district organizations (CDOs) has tended to be static and cross-sectional; the current literature does not address the key criterion of economic restructuring, let alone potential changes in district organizational structure, financing, and activities in the wake of increasing economic stress in cities and to their constituent business base. Questions addressed in this research are:

-What are the key differences between different types of commercial district organizations? 
- How do these differences affect the success of these organizations?

- Have CDOs responded effectively to contextual changes and new economic realities?

\section{Commercial District Organizations}

Downtown Development Authorities and Business Improvement Areas share a number of important characteristics. Each is created through formal action by the local government, within parameters established by State/Provincial statutes and includes multiple commercial properties. A major concern of both types of organization is to assist established business districts in adapting to modern retailing concepts. The organizational structure and legal powers of commercial district management organizations vary considerably, however (Morcol \& Wolf, 2010). Both models are popular in situations ranging from traditional city centers in large urban areas through small towns, suburban communities and neighborhood commercial areas.

\subsection{Business Improvement Areas}

Business Improvement Areas (Note 1) originated in Canada but have been adopted globally (Hoyt, 2006; Ward, 2006; Morcol \& Wolf, 2010; Ruffin, 2010). Common attributes of BIAs are: a geographically defined area in which extra taxes are imposed to provide additional services; a means of limiting those services to the area so that few spill-overs occur; and, a governing board composed largely of business owners (Billings \& Leland, 2009). Business Improvement Areas may undertake a wide range of activities, often well beyond those common to voluntary merchant associations. These may include promotion, environmental maintenance (litter control, landscaping) and public safety. The BIA may also make improvements to public spaces (flower baskets, street furniture, banners, lighting), undertake market research and event coordination (for example, concerts and other activities to attract visitors).

Business Improvement Areas are financed by an additional tax on business properties. These revenues, like TIF revenues, are spent on activities that benefit the BIA; the difference is that generating the revenues increases the businesses' costs. The BIA membership establishes the amount of the levies, which are typically collected by the municipality along with property taxes. Local government participation precludes "free riders".

\subsection{Downtown Development Authorities}

Despite the name, Downtown Development Authorities are not limited to the traditional central business districts of cities but are found in suburbs and small towns as well. Governance for DDAs is established by local ordinances, which typically specify that the members must be a combination of public officials and persons with an interest in the district. The distinguishing characteristic of Michigan DDAs is their reliance on tax increment financing. Tax increment financing allows municipalities to undertake important and costly improvements, particularly when bond financing is required, without levying new taxes. (Note 2) Once a TIF district has been established, any subsequent growth in aggregate property tax revenues, resulting either from new construction or from rising values of existing properties, is "captured" by the district for use within the area. The property tax rates are the same within the tax increment finance district as elsewhere in the community; the incentive for being included in the district is that taxes paid result directly in public expenditures in the district. Downtown Development Authorities may use revenue from TIF districts for a range of activities, including ongoing operating expenses, infrastructure improvements (parking decks and street improvements for example), and subsidies to firms or community events. Michigan DDAs do not have an automatic "sunset" and must continue to exist so long as the repayment of any bonded debt is required.

\section{Literature Review}

Since the 1970s, TIF has become one of the most popular economic development tools, particularly in conjunction with DDAs (Forgey, 1993). In part, its popularity lies in the presumptive development benefits: municipalities do not have to increase property taxes to pay for desired improvements; for business owners in the TIF districts, higher levels of services can be provided without paying higher taxes. Michigan DDAs are allowed to use revenue bond financing, reducing the time required to initiate expensive capital improvements (Weber, 2003; Sands et al., 2007). DDAs provide a wide array of services, including capital projects, marketing, economic development, maintenance, parking/transportation, public policy advocacy, regulation of public space, security, and even social services (Huey et al., 2005; Lippert, 2007; Lippert \& Sleiman, 2012; MacDonald, 1996; Lewis, 2010).

Although CDOs have existed for decades, systematic evaluations have reached mixed conclusions as to their impacts. Some studies have found that BIAs are associated with reduced crime rates and increases in the value of property; they have also been found to be efficient providers of services, (Ross \& Levine, 2001; Symes \& Steel, 2003; Hoyt, 2006; Lewis, 2010), in some cases more effectively than local governments (Traub, 1996). The 
services provided by the BIAs appear to be complementary to, rather than competitive with, city services and solve the free-rider problems experienced by more generalized business organizations such as Chambers of Commerce (Billings \& Leland, 2009).

BIAs may face greater challenges in raising sufficient revenue to fund major capital improvements, such as parking decks. Business Improvement Areas are generally funded by an additional levy on property owners. BIAs are a "tax enhancement strategy" (Gross, 2005) which turn policies such as tax incentives on their head as the private sector is, in essence, agreeing to pay increased taxes (Kantor \& Savitch, 1998). Because this effectively adds to the property tax burden of the businesses, the actual amount of the BIA tax may be relatively small, limiting the activities of the BIA. Larger BIAs are more likely to engage in capital improvements while smaller ones are more limited to maintenance and promotion. BIAs appear more likely to form in areas with higher property values and at least some economic growth (Meltzer, 2012).

A common criticism of DDAs is their use of tax increment financing. TIF revenues are not available to support general services; thus, city-wide tax rates may increase to ensure that public service levels outside of the district are maintained (Weber, 2003; Sands et al., 2007). TIF can be problematic if sunset provisions are not included. TIF districts are governed by boards that lack transparency and accountability, and TIF is only likely to be effective when new development does in fact occur or where property values are increasing, thus the original designation should be done carefully (Sands et al., 2007).

Measuring success of CDOs is difficult because it requires identifying the unique contribution of the organization to the success of a business district. There is no counterfactual available-what would have happened to the business district if the CDO did not exist. Further, because CDOs tend to work collaboratively with local governments and other business groups such as Chambers of Commerce, it is difficult to isolate the impacts of the CDO alone (Mitchell, 2008).

As this review of the literature shows, there is a dearth of research examining the roles of commercial district organizations in, and their reactions to, changes in the local economy. No work has explicitly compared the different district structural options. Even the work post-great recession, has not explicitly focused on potential changes in both the nature of CDO members and the activities of the organization. Turner $(2002$, p. 533) suggested that the nature of larger city downtowns has been changing from places of consumption and commerce serving local residents to places "designed more like amusement parks for tourists". She argues that downtown changes as of the early 2000s included: a shift from public to private space; more brand name and fewer local stores; increasing loft and town home housing; and emphasis on middle and high income consumers. But, in some cases, she also found efforts at a broader governance structure for local commercial district organizations. Again, two major questions remain unanswered - have such changes continued in the wake of the Great Recession, and are these processes only applicable to large cities or those with particular types of downtowns? In short, many interesting questions remain unanswered, most prominently, whether the goals and activities of CDOs have changed as local economies have and whether more adaptable CDOs experience better outcomes.

\section{Methodology}

This research is based on a survey of Downtown Development Authorities in Michigan and Business Improvement Areas across Canada. The DDA population was identified through lists obtained from the Citizens Research Council of Michigan (2010), web searches, and trade association publications. The Ontario Business Improvement Area Association and web searches were used to identify the population of BIAs.

Each of the organizations received an electronic survey form; organizations without email contact information, as well as those that did not wish to complete an online survey, were sent mailed questionnaires. A French language version of the survey was made available upon request. To increase response rates, respondents were sent at least three email requests to answer the electronic survey. Non-respondents then received a mailed questionnaire. Post card reminders were also used.

Responses were provided by 119 of the 379 active Downtown Development Authorities surveyed. The overall response rate of $31.4 \%$ is typical for this type of survey. The geographic representation is good; that is, the responses represent rural and urban locations in all areas of the State. DDAs in Michigan's largest cities, those with population's over 50,000 are somewhat under represented (See Figure 1). 


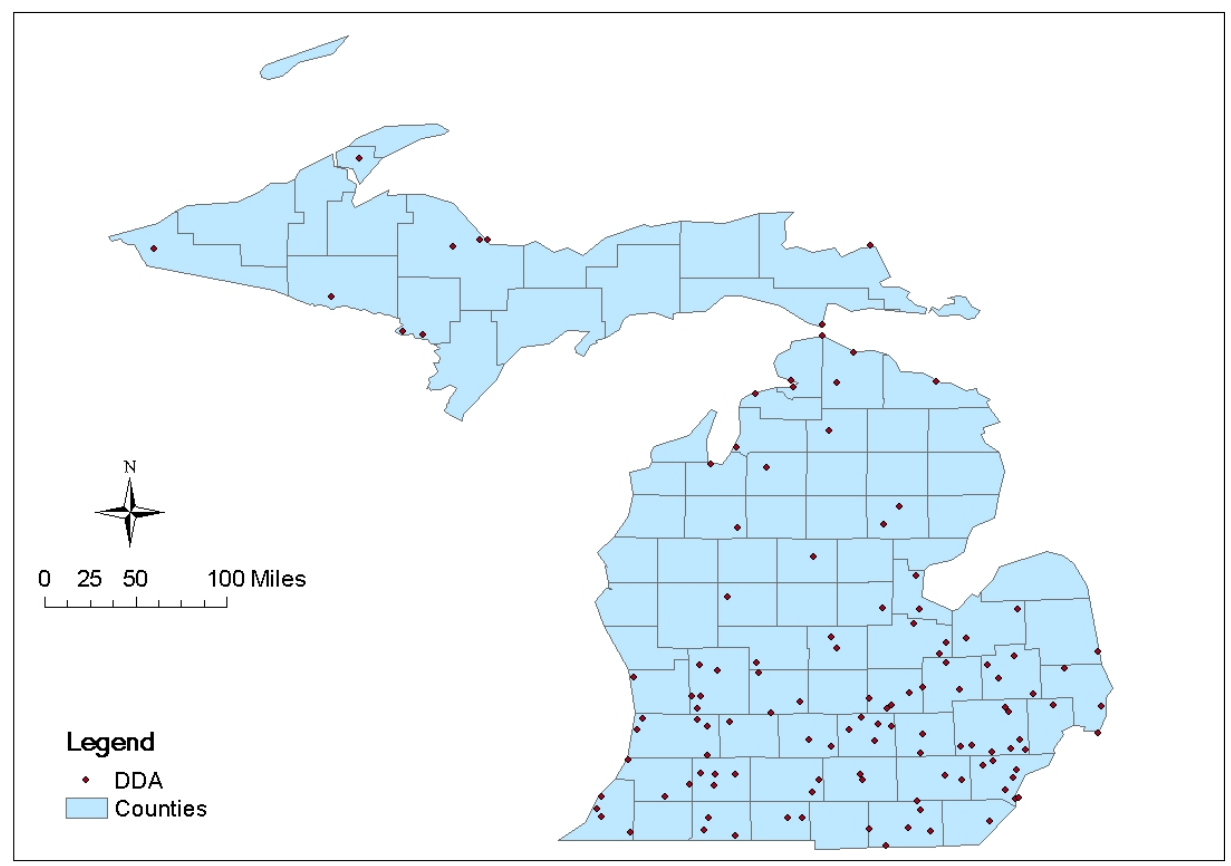

Figure 1. Location of respondents to DDA survey

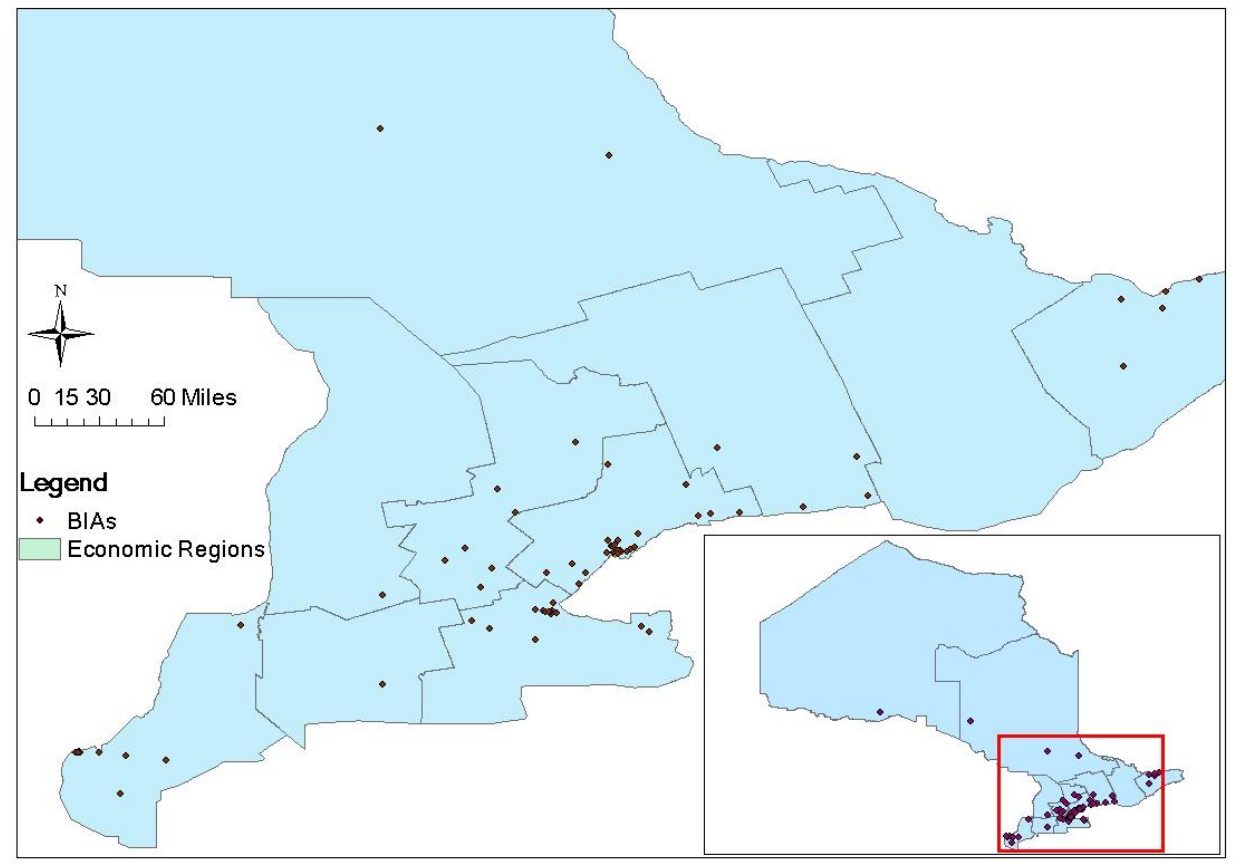

Figure 2. Location of respondents to BIA survey

A total of 84 responses were received from the 299 BIAs, a response rate of $28.1 \%$. With one exception (Prince Albert, SK) all of the responses came from organizations in Ontario and British Columbia. Responses came from the largest cities in these Provinces, as well as from smaller communities in more rural areas. (See Figure 2)

4.1 Respondent Profile

The BIA respondents include both city center and neighborhood BIAs. Most of the city center BIAs that 
responded are located in smaller municipalities. Neighborhood shopping districts represented the majority of BIA respondents (Table 1). The larger cities in Ontario and British Columbia-Toronto (16), Hamilton (8), Windsor (3), Ottawa (3) and Vancouver (4) - account for almost two-thirds of neighborhood commercial district respondents. Response data are reported separately for these two types of BIA, although the differences between then are frequently not significant.

The Michigan responses came from three types of municipalities: cities, townships and villages. Each of these has different powers and responsibilities. Michigan cities range in population size from less than 500 to about 700,000 . Villages have much less authority and are generally small, with an average population of about 1,000. Townships generally provide limited public services to rural areas, although townships in suburban locations (most of those responding to the survey) have larger populations and provide more services. Cities and villages are well represented in the survey but townships are not.

The oldest DDA in the survey was established in 1971, the newest in 2009. About half were created between 1984 and 1994. The average number of establishments in these DDAs is 152 . The median number of businesses is 89 ; the range is from 3 to 1500 . The number of establishments per DDA was highest in cities and lowest in villages.

Table 1. Profile of respondents

\begin{tabular}{lccccccc}
\hline & City & Township & Village & DDA & City Center & Neighborhood & BIA \\
\hline Number of respondents & 71 & 18 & 31 & $\mathbf{1 2 0}$ & 32 & 52 & $\mathbf{8 4}$ \\
Median year established & 1986 & 1992 & 1992 & $\mathbf{1 9 8 7}$ & 1982 & 1987 & $\mathbf{1 9 8 5}$ \\
Number of establishments & 200 & 124 & 50 & $\mathbf{1 5 2}$ & 279 & 313 & $\mathbf{3 0 0}$ \\
Total staff mean & 2.21 & 1.40 & 1.58 & $\mathbf{2 . 0 1}$ & 2.70 & 2.25 & $\mathbf{2 . 4 9}$ \\
With no employees & $38 \%$ & $50 \%$ & $53 \%$ & $\mathbf{4 3 \%}$ & $17 \%$ & $28 \%$ & $\mathbf{2 4 \%}$ \\
Number of volunteers & 22.9 & 15.5 & 9.2 & $\mathbf{2 1 . 1}$ & 9.9 & 8.8 & $\mathbf{9 . 2}$ \\
\hline
\end{tabular}

The DDAs surveyed generally employ very limited staff. Most (68 percent) have no full time staff; only seven reported having two or more full time staff. The most common arrangement is to utilize part time staff. About 56 percent of the DDAs have only part time employees; three-quarters of these rely exclusively on part time employees. In many cases, the DDA staff are full time municipal employees, such as the City Manager or Community Development Director, who devote some time to managing the DDA. Close to 40 percent of the respondents reported utilizing volunteers, with the reported number of volunteers ranging up to 300; 17 DDAs rely exclusively on volunteers.

BIAs typically include more establishments than the DDAs, because tenants are included as well as property owners. The Neighborhood BIAs have more members than do the City Center districts. The BIAs surveyed indicated that they typically had more paid staff than the DDAs. While the differences are just a fraction of a person in both the full and part time employee categories, more than three-quarters of the BIAs have some paid staff, compared to about half of the DDAs.

\subsection{Businesses Included in the Districts}

Both DDAs and BIAs include a wide range of business types. The survey listed ten broad categories of business establishments, which can be grouped in four general categories: Retail, Entertainment, Shopping and Culture/Tourism. Two-thirds of the BIAs responding, and three-quarters of the DDAs, reported that they had a moderate to high proportion of businesses in one or more of these categories (Table 2). The most common concentration was the Entertainment category, which includes restaurants, bars and clubs; 60 to 75 percent of respondents reported this specialization. The Canadian BIAs were about twice as likely to report a concentration of businesses in the other three categories. With the exception of township DDAs, the subgroups have similar proportions of businesses in each of the four categories. Township DDAs were less likely to have high concentrations of Retail and Culture/Tourism establishments. 
Table 2. Moderate to high concentrations of establishments by type

\begin{tabular}{llccccc}
\hline & No Dominant & Entertainment & Retail & Office & Culture/Tourism \\
\hline DDA & City & $30 \%$ & $64 \%$ & $31 \%$ & $30 \%$ & $6 \%$ \\
& Township & $37 \%$ & $56 \%$ & $6 \%$ & $19 \%$ & $0 \%$ \\
& Village & $35 \%$ & $61 \%$ & $16 \%$ & $13 \%$ & $16 \%$ \\
& TOTAL & $\mathbf{3 3 \%}$ & $\mathbf{6 3 \%}$ & $\mathbf{2 4 \%}$ & $\mathbf{2 4 \%}$ & $\mathbf{8 \%}$ \\
\hline BIA & City Center & $10 \%$ & $83 \%$ & $50 \%$ & $47 \%$ & $27 \%$ \\
& Neighborhood & $12 \%$ & $72 \%$ & $35 \%$ & $52 \%$ & $15 \%$ \\
& TOTAL & $\mathbf{1 2 \%}$ & $\mathbf{7 8 \%}$ & $\mathbf{4 1 \%}$ & $\mathbf{5 0 \%}$ & $\mathbf{1 9 \%}$ \\
\hline
\end{tabular}

Both groups reported that their business base was relatively stable; 71 percent of all DDA respondents indicated that the number of businesses in each category had remained stable over the previous five years, roughly 2007-12. The proportion of BIAs reporting a stable number of businesses was 63 percent; however, an additional 29 percent reported increases. Almost one-quarter (23\%) of the DDAs reported that the number of businesses in each category had actually increased. Declines were reported to have occurred in an average of seven to eight percent of the districts.

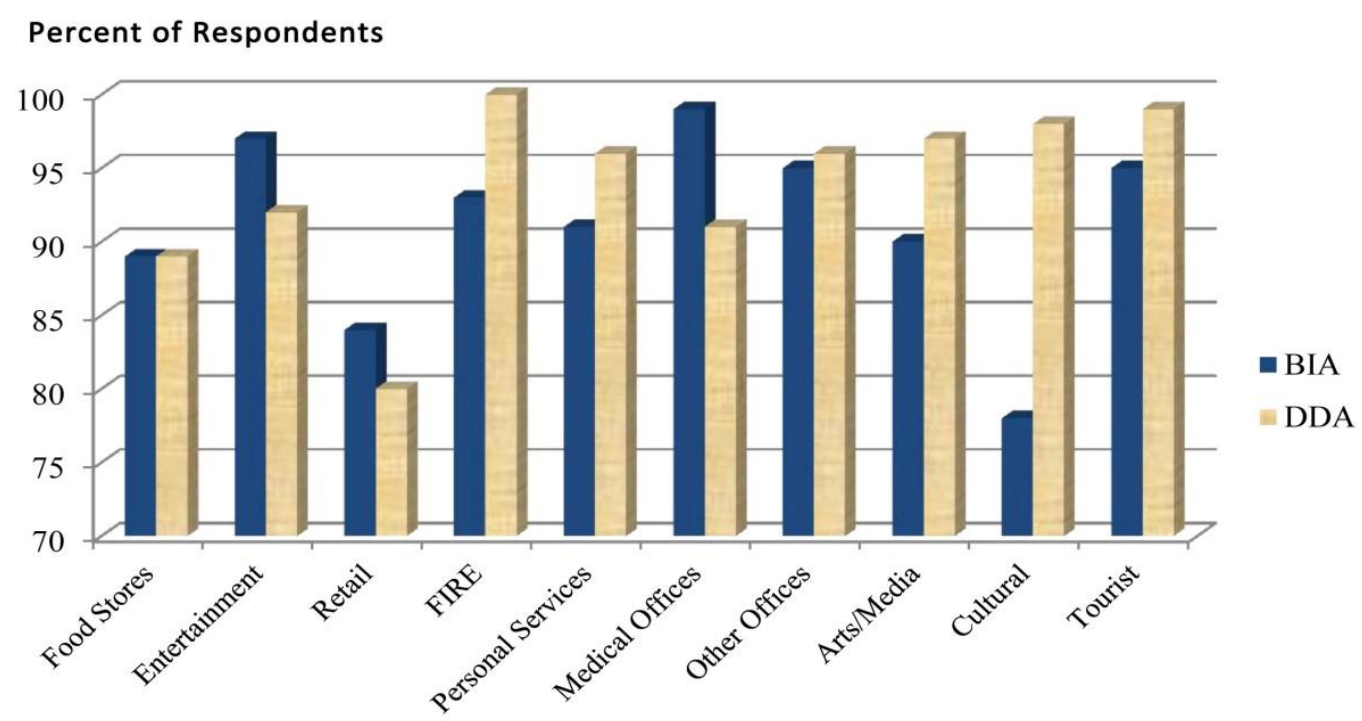

Figure 3. Stable or increasing numbers of establishments

\section{Organization Attributes}

\subsection{Sources of Funding}

Table 3 indicates the primary funding sources for both types of CDO. Member contributions are a moderate or high source of funding for 88 percent of BIAs. For the DDAs, 69 percent reported that the majority of their funding came from TIF revenue. Over three-quarters of the DDAs indicated that they received no funds from member contributions; none of the BIAs reported TIF revenue. Revenue from other sources, such as operations and grants, was important for only a small proportion of the respondents. 
Table 3. Sources of funding

\begin{tabular}{|c|c|c|c|c|}
\hline & \multicolumn{2}{|c|}{ DDA } & \multicolumn{2}{|c|}{ BIA } \\
\hline & None & Moderate or High & None & Moderate or High \\
\hline Members & $78 \%$ & $12 \%$ & $3 \%$ & $88 \%$ \\
\hline Operations & $30 \%$ & $5 \%$ & $32 \%$ & $11 \%$ \\
\hline Grants & $60 \%$ & $9 \%$ & $54 \%$ & $3 \%$ \\
\hline TIF & $34 \%$ & $61 \%$ & -- & -- \\
\hline Other & $18 \%$ & $18 \%$ & $57 \%$ & $23 \%$ \\
\hline
\end{tabular}

For the past five years, revenues from most sources have remained stable or increased, particularly for BIAs. Two percent of BIA respondents reported a decrease in income from members and three percent had less grant income. Revenue trends for DDAs are somewhat more negative, one of every five DDAs reported a decline in TIF revenue, five to eight percent of respondents indicated declining revenues in the other categories. Revenue from operations had the largest increase, 44 and 28 percent for BIAs and DDAs, respectively. The Great Recession of the last decade was more severe in the United States, contributing to the decline in the primary source of revenue for DDAs. Although most DDAs have managed to increase funding from other sources, BIAs appear to be much more aggressive in diversifying their revenue sources.

\subsection{Primary Activities}

Respondents were asked to indicate the level of expenditures that they devoted to six different activities (Table 4). The BIAs focused their efforts on three areas: Operational Costs, Events and Area Appearance, each of which represented at least one-third of the annual budget for two of every five BIAs. Surprisingly, a substantial portion of the BIAs indicated relatively low levels of spending on public safety and cleanup, traditionally mainstays of BIA operations. The respondents indicated that over the past five years expenditures in each category had remained stable or increased, with increased spending occurring most frequently on Area Appearance, Events and Capital Improvements.

DDAs were likely to spend large proportions of their budget on Capital Improvements in the district (40\% of DDAs), followed by Operations (22 percent). Area appearance and Events were major expenditure items for roughly one of every six DDAs. Three of four DDAs reported no direct spending on Public Safety; almost half (46 percent) spent nothing on Cleanup activities. Although a majority of the DDAs reported that expenditures in each category had been stable or increased over the past five years, DDAs were much more likely than BIAs to report declines in spending. The proportion of DDAs reporting spending declines was in excess of ten percent for every activity except Public Safety, a service that relatively few of the respondents provided. More DDA respondents reported decreases than increases in their expenditures on Operations, Area Appearance and Cleanup; the net declines were $11 \%, 10 \%$ and $5 \%$, respectively.

Table 4. Level of expenditures by activity

\begin{tabular}{|c|c|c|c|c|c|c|}
\hline & \multicolumn{2}{|c|}{ None } & \multicolumn{2}{|c|}{ Less than $1 / 3$} & \multicolumn{2}{|c|}{$1 / 3$ or more } \\
\hline & BIA & DDA & BIA & DDA & BIA & DDA \\
\hline Operations & $5 \%$ & $16 \%$ & $57 \%$ & $62 \%$ & $38 \%$ & $22 \%$ \\
\hline Capital Improvements & $35 \%$ & $18 \%$ & $50 \%$ & $43 \%$ & $16 \%$ & $40 \%$ \\
\hline Cleanup & $29 \%$ & $46 \%$ & $64 \%$ & $49 \%$ & $8 \%$ & $6 \%$ \\
\hline Safety & $59 \%$ & $75 \%$ & $33 \%$ & $22 \%$ & $8 \%$ & $3 \%$ \\
\hline Appearance & $3 \%$ & $15 \%$ & $51 \%$ & $68 \%$ & $47 \%$ & $15 \%$ \\
\hline Events & $4 \%$ & $26 \%$ & $44 \%$ & $58 \%$ & $52 \%$ & $17 \%$ \\
\hline
\end{tabular}




\section{Self-Assessment}

\subsection{Success}

The survey asked respondents to indicate how successful they had been in achieving their goals and objectives. None of the CDOs reported that they have been completely successful and only eight (two BIAs and six DDAs) indicated that they had had no success at all. Just over half of the BIAs $(51 \%)$ reported moderate success, compared to $43 \%$ of the DDAs.

In general, there are few attributes that have a significant correlation with this self-assessment of success. There were no significant correlations between success and geographic location (city center or neighborhood), types of businesses, funding sources, staff size and organizational priorities. The relatively few items that did produce significant correlations with success are primarily associated with expenditure levels - specifically what were the dominant expenditure categories. The success of DDAs was positively and significantly associated with high levels of spending on Capital improvements $\left(\mathrm{r}^{2}=.201\right.$, sig. $\left.=.042\right)$ and organizational operations $\left(\mathrm{r}^{2}=.215\right.$, sig. $=.030)$. BIA success, on the other hand, was positively and significantly related to expenditures on cleanup $\left(\mathrm{r}^{2}\right.$ $=.334$, sig. $=.008)$ and public safety $\left(\mathrm{r}^{2}=.354\right.$, sig. $\left.=.008\right)$. In effect, the CDOs were more likely to consider themselves successful it they invested heavily in the primary activities for their organizational type.

The only other significant correlate with success was in the BIA data. There was a strong negative correlation $\left(\mathrm{r}^{2}\right.$ $=-.380$, sig. $=.005$ ) between estimate of success and changes in priority. BIAs were more likely to change their priorities if they did not feel they had been particularly successful.

\subsection{Effectiveness}

When asked what were their most effective activities, the BIAs were most likely to indicate that the Events that they sponsored were most effective (Table 5), followed by Services to members. Less than five percent of the BIAs indicated effectiveness in providing Capital Improvements. For the DDAs Appearance Improvements and Capital Improvement Projects were their most effective areas. Services to Members was another area in which DDAs felt they were effective.

\subsection{Ineffectiveness}

Commercial Development Organizations in both countries were most likely to report that they were ineffective in providing Services to Members, with almost half of the respondents in each group listing this as a problem area. DDAs were more likely to be ineffective in Capital Improvement Projects than the BIAs, most likely because the former were more involved with them. The opposite was found for Events; BIAs were more involved with Events and thus encountered more difficulties.

Table 5. Effective and ineffective activities

\begin{tabular}{|c|c|c|c|c|}
\hline & BIA & & DDA & \\
\hline Effective & $\%$ of First Responses & $\%$ of All Responses & $\%$ of First Responses & $\%$ of All Responses \\
\hline Appearance & 16 & 18 & 37 & 30 \\
\hline Marketing & 10 & 19 & 4 & 12 \\
\hline Capital Projects & 3 & 4 & 24 & 22 \\
\hline Events & 54 & 36 & 14 & 14 \\
\hline \multirow[t]{2}{*}{ Member Services } & 17 & 22 & 21 & 23 \\
\hline & BIA & & DDA & \\
\hline Ineffective & $\%$ of First Responses & $\%$ of All Responses & $\%$ of First Responses & $\%$ of All Responses \\
\hline Appearance & 11 & 10 & 6 & 5 \\
\hline Marketing & 9 & 10 & 13 & 10 \\
\hline Capital Projects & 13 & 14 & 20 & 23 \\
\hline Events & 22 & 20 & 10 & 9 \\
\hline Member Services & 44 & 48 & 51 & 53 \\
\hline
\end{tabular}




\subsection{Obstacles}

DDAs and BIAs reported different obstacles to their successful operations (Figure 4). For BIAs, almost one-third of the respondents indicated that their efforts were hampered by insufficient member participation, followed by the availability of adequate funding. In the responses from the DDAs, the ranking of these items were reversed. Twelve percent of the DDAs indicated that the poor performance of the local economy has been an obstacle. The adequacy of available infrastructure was cited as an obstacle by one of every six BIAs.

\section{Percent of Respondents}

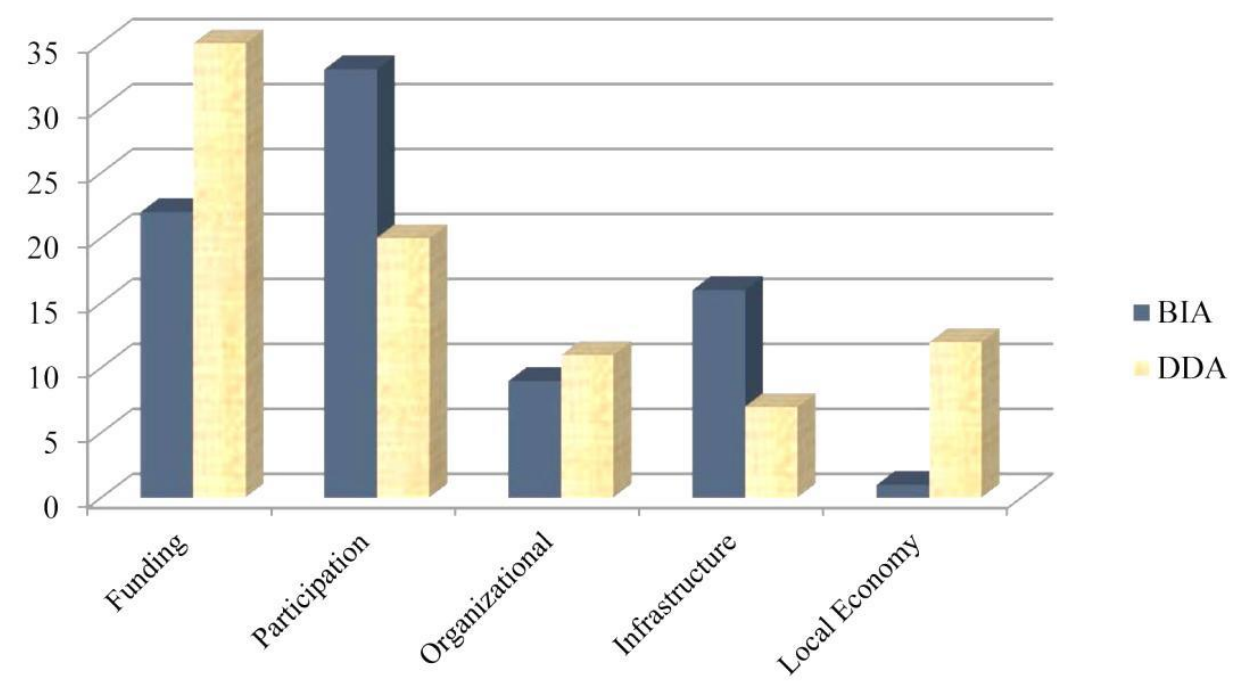

Figure 4. Obstacles to success

\section{Adaptability}

\subsection{District Priorities}

Three out of five DDAs indicated that they have a diverse set of goals; that is, their top five objectives represented five different categories. Almost one-quarter of the respondents indicated that physical improvements were their top priority; in two instances all five of their most important objectives related to physical improvements. Business development, the retention or attraction of businesses to downtown, was the top priority of about ten percent of DDAs. Improving the appearance of downtown was a priority for five respondents, as were a variety of organizational objectives.

Respondents were asked to write in their top five priorities, in order of importance. The results are summarized in Table 6. By far the most common category was the provision of physical improvements, such as street improvements, lighting and other infrastructure. Capital improvement projects were the most commonly mentioned activity in each of the four top categories. Well behind were business development, DDA operations (including finance issues) and events and marketing. Business development was often the number one priority of the DDA; events and marketing were given somewhat lower priority, generally second to fourth. It is interesting to note that very few of the DDAs reported priorities related to Quality of life - such as sustainability and safety. When these topics were cited, it was most often at a lower ranking. Thus, in comparison to the forced-choice question about activities the DDA spent revenues on, goals were much more likely to continue to be focused on capital improvements when respondents were allowed to identify their own goals and priorities. 
Table 6. Priority objectives

\begin{tabular}{|c|c|c|c|c|}
\hline & \multicolumn{2}{|l|}{ BIA } & \multicolumn{2}{|l|}{ DDA } \\
\hline & $\%$ of First Responses & $\%$ of All Responses & $\%$ of First Responses & $\%$ of All Responses \\
\hline Appearance & 12 & 12 & 15 & 12 \\
\hline Business Development & 42 & 33 & 23 & 33 \\
\hline Capital Improvements & 10 & 16 & 31 & 16 \\
\hline Events & 7 & 10 & 1 & 10 \\
\hline Organizational & 28 & 27 & 31 & 27 \\
\hline Quality of Life & 1 & 2 & 0 & 2 \\
\hline
\end{tabular}

\subsection{Changes in Priorities}

Cities, and their commercial districts, may be more resilient to economic crises if they are able to be adaptable to changing economic conditions. Among respondents, BIAs were slightly more likely (63\% v 59\%) to report that they had revised their priorities in the past five years. The reasons for these changes, however, differed considerably. DDAs indicated that they had changed their priorities because of changes in the local economy. This reason was cited much more frequently than any other.

On the other hand, BIAs revised their priorities primarily as a result of a Board initiative. This result is consistent with the "grass roots" nature of the BIA Boards. Other reasons for changing priorities (competition, changing membership) were mentioned much more frequently by BIA respondents than DDA respondents.

Changes in spending levels were rarely associated with formal changes in organizational priorities. DDAs reporting a change in priorities were more likely to increase their spending on Area Appearance. On the other hand, BIAs that revised their priorities tended to decrease their spending on operation of the organization. None of the other changes in spending has a statistically significant association with changes in priorities.

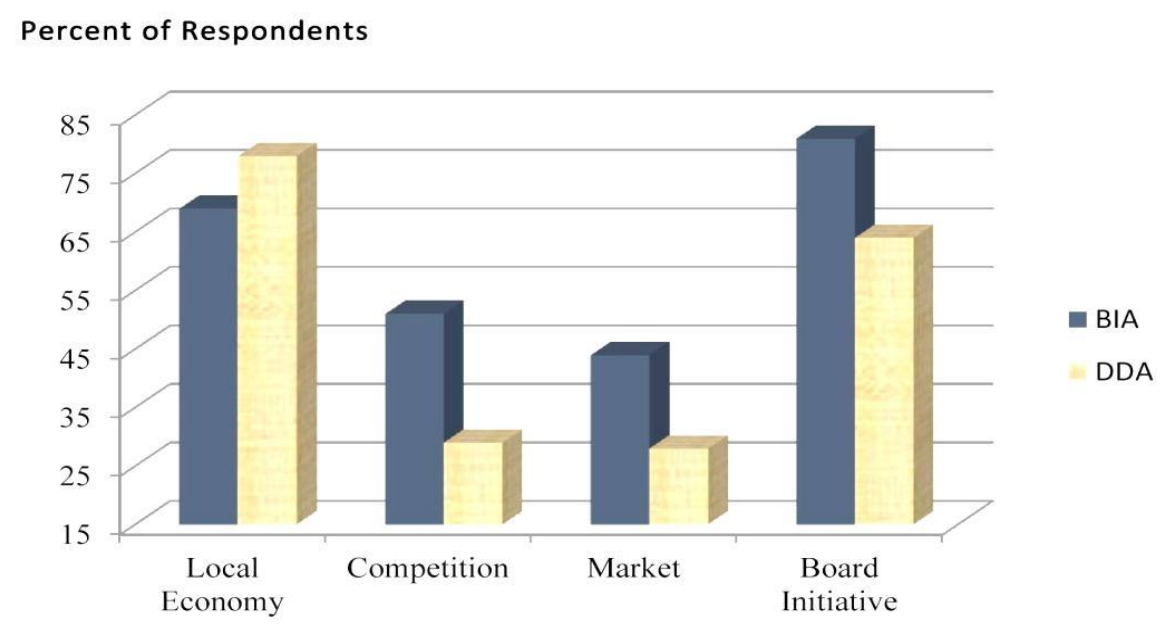

Figure 5. Moderate or significant effects on priorities

\section{Discussion}

Many of the observed differences between Business Improvement Associations and Downtown Development Authorities are related to their governance structures and their primary funding sources. DDA directors are usually appointed by the municipality that created the Authority. In most instances, not all Board members are property or business owners in the district. For those DDAs created for the primary (or sole) purpose of issuing TIF bonds to finance capital improvements, staffing of the DDA often consists of local government officials who manage DDA operations on a part time basis. 
While not all DDAs have a significant income stream from the incremental growth in the tax base, most Authorities can count on steadily increasing revenues. Even when the DDA's primary function is financing capital improvements with revenue bonds, continued growth of the tax base will generate increasing annual revenues. The surplus over and above the amounts required for bond payments becomes available for other activities.

Although Business Improvement Areas are also created by local governments, their Boards are usually elected by the membership, which includes both property owners and business tenants. The majority of the Board members must have an interest in the Area. The Board is responsible for hiring staff, setting the budget and providing overall policy direction for BIA activities. BIAs are funded by an additional tax levy on property within the district. (Note 4) Because this additional tax must be approved annually by the membership, BIA budgets are more limited and subject to change from year to year, making bond financed projects more difficult.

Despite these differences, both DDAs and BIAs typically have similar operational profiles. They both undertake marketing campaigns, events to bring customers to the area, beautification projects and member services. Public safety is a surprisingly low priority for both types of organizations.

There are, however, some important differences. Business development activities are a higher priority among BIAs while capital improvements are the highest priority for DDAs. A mature DDA may face the "problem" of determining how the available funds should be spent; BIAs must find funds for the projects that they wish to undertake. This difference seems to have contributed to the BIAs more aggressive attempts to diversify their revenue sources. The BIA Boards are also more likely to take the initiative in adjusting their priorities and programs in the face of changing circumstances. The DDAs, on the other hand, seem more cautious, changing mostly in response to changes in the local economy.

Which model of commercial district organization is a better choice depends on the specific circumstances. The results of this study certainly support the use of a TIF-funded DDA to undertake large scale capital improvement projects. For most other activities, a BIA seems to provide a more flexible and responsive organizational structure.

\section{Acknowledgements}

Financial support for this study was provided by the Canadian Embassy in Washington DC and the Government of Quebec.

\section{References}

Billings, S. B., \& Leland, S. (2009). Examining the logic behind the self-help, self-taxing movement: Business improvement district formation. Public Budgeting and Finance, Winter, 108-124. http://dx.doi.org/10.1111/j.1540-5850.2009.00945.x

Blakely, E., \& Snyder, M. (1997). Fortress America: Gated Communities in the United States. Washington DC: The Brookings Institution Press.

Citizens Research Council of Michigan (CRC). (2010). Survey of Economic Development Programs in Michigan. Livonia MI: CRC.

Forgey, F. (1993). Tax increment financing: Equity, effectiveness, and efficiency. The Municipal Yearbook. Washington DC: International City/County Management Association.

Gross, J. S. (2005). Business improvement districts in New York City's low-income and high-income $\begin{array}{lllll}\text { neighborhoods. } \quad \text { Economic Development } & \text { Quarterly, } & 19,\end{array}$ http://dx.doi.org/10.1177/0891242404273783

Hoyt, L. (2006). Importing ideas: The transnational transfer of urban revitalization policy. International Journal of Public Administration, 29, 221-243. http://dx.doi.org/10.1080/01900690500409096

Huey, L., Ericson, R., \& Haggerty, K. (2005). Policing fantasy city. In D. Cooley (Ed.), Re-Imaging Policing in Canada (pp. 140-208). Toronto: University of Toronto Press.

Johnson, C., \& Man, J. (2001). Tax Increment Financing and Economic Development: Uses, Structures, and Impact. Albany: State University of New York Press.

Kantor, P., \& Savitch, H. (1998). Can politicians bargain with business? A theoretical and comparative perspective on urban development. In D. Judd \& P. Kantor (Eds.), The Politics of Urban America (pp. 288296). Needham Heights, MA: Allyn \& Bacon.

Lewis, N. M. (2010). Grappling with governance: The emergence of business improvement districts in a national 
capital. Urban Affairs Review, 27(August), 180-217. http://dx.doi.org/10.1177/1078087410378844

Lippert, R. (2007). Urban revitalization, security, and knowledge transfer: The case of broken windows and kiddie bars. Canadian Journal of Law and Society, 22, 29-54.

Lippert, R., \& Sleiman, M. (2012). Ambassadors, business improvement district governance and knowledge of the urban. Urban Studies, 49(1), 61-76. http://dx.doi.org/10.1177/0042098010396235

MacDonald, H. (1999). BIDs really work. City Journal, 6, 29-42.

Meltzer, R. (2011). Understanding business improvement district formation: An analysis of neighborhoods and boundaries. Journal of Urban Economics, 71, 66-78. http://dx.doi.org/10.1016/j.jue.2011.08.005

Mitchell, J. (2008). Business Improvement Districts and the Shape of American Cities. Albany: State University of New York Press.

Morcol, G., \& Wolf, J. F. (2010). Understanding business improvement districts: A new governance framework. Public Administration Review, November/December, 906-913. http://dx.doi.org/10.1111/j.1540-6210.2010.02222.x

Ross, B. H., \& Levine, M. A. (2001). Urban Politics: Power in Metropolitan America (6th ed.). Itasca, IL: F. E. Peacock.

Ruffin, F. A. (2010). Collaborative network management for urban revitalization. The business improvement district model. Public Performance and Management Review, 33(3), 459-487. http://dx.doi.org/10.2753/PMR1530-9576330308

Sands, G., Reese, L. A., \& Trudeau, K. (2007). Tips for TIFs: Policies for Neighborhood Tax Increment Financing Districts. Journal of the Community Development Association, 38(Summer), 68-86. http://dx.doi.org/10.1080/15575330709489840

Stokes, R. J. (2007). Business improvement districts and small business advocacy: The case of San Diego's citywide BID program. Economic Development Quarterly, 21, 278-291. http://dx.doi.org/10.1177/0891242407302325

Symes, M., \& Steel, M. (2003). Lessons from America: The role of business improvement districts as an agent of urban regeneration. Town Planning Review, 74(3), 301-313. http://dx.doi.org/10.3828/tpr.74.3.3

Traub, J. (1996). Can associations of businesses be true community builders? The Responsive Community, 29 , $28-32$.

Turner, R. S. (2002). The politics of design and development in the postmodern downtown. Journal of Urban Affairs, 24, 533-548. http://dx.doi.org/10.1111/1467-9906.00142

Weber, R. (2003). Equity and entrepreneurialism the impact of tax increment financing on school finance. Urban Affairs Review, 38, 619-644. http://dx.doi.org/10.1177/1078087403038005001

\section{Notes}

Note 1. The Business Improvement Areas nomenclature is common in English Canada; comparable organizations are referred to as Sociétés de développement commercial in French Canada and Business Improvement Districts (BID) in the United States.

Note 2. TIF-backed bonds are generally not backed by the full faith and credit of the municipality and, in some states, are outside municipal debt limits.

Note 3. The limited range of responses contributes to the lack of significance.

Note 4. Although the BIA levy is added to the property tax bill, businesses who lease their premises contribute through their rental payments.

\section{Copyrights}

Copyright for this article is retained by the author(s), with first publication rights granted to the journal.

This is an open-access article distributed under the terms and conditions of the Creative Commons Attribution license (http://creativecommons.org/licenses/by/3.0/). 